\title{
Comparison of Mangalica and Hungarian Large White pigs at identical bodyweight: 1. Backfat histology (Short Communication)
}

\author{
ANDRÁS SZABÓ ${ }^{1}$, ANNA VISKI ${ }^{2}$, ZSOLT EGYHÁZI ${ }^{2}$, ZOLTÁN HÁZAS ${ }^{1}$, PÉTER HORN ${ }^{1}$ \\ and RÓBERT ROMVÁRI ${ }^{1}$
}

'Laboratory of Animal Product Qualification, Faculty of Animal Science, Kaposvár University, Kaposvár, Hungary, ${ }^{2}$ Kaposi Mór Hospital, Department of Pathology, Kaposvár, Hungary

\section{Abstract}

At $130 \mathrm{~kg}$ bodyweight Mangalica and Hungarian Large White pig adipose tissue was compared, by means of histology. Adipose cell diameter (117.2 \pm 24.1 vs. $55.3 \pm 17 \mu \mathrm{m}$, Mangalica vs. Hungarian Large White), size $\left(118.9 \pm 44.3\right.$ vs. $\left.31.9 \pm 0.63 \mu \mathrm{m}^{2} \cdot 100\right)$ and volume $\left(8.01 \pm 0.67\right.$ vs. $\left.2.18 \pm 0.18 \mu \mathrm{m}^{3} \cdot 1000\right)$ was significantly higher in Mangalica, while the hydroxyproline content $(0.04 \pm 0.005$ vs. $0.23 \pm 0.014$ weight $\%$ of wet tissue) and the connective tissue area in the microscopic images (\%) were ca. 5 -fold higher in Hungarian Large White. The present quantitative results underscore the experience that at identical bodyweight the fat $(89.9 \pm 1.19$ vs. $78.9 \pm 0.39 \%)$ and dry matter content $(97.8 \pm 1.72$ vs. $87.7 \pm 0.38 \%$, Mangalica vs. Hungarian Large White), as well as the cellularity of Mangalica largely differs from that of Hungarian Large White.

Keywords: pig, Mangalica, Hungarian Large White, adipose tissue, connective tissue, histology

\section{Zusammenfassung}

\section{Vergleich zwischen Mangalitza und Ungarischem Large White bei gleichem Lebendgewicht: 1. Histologie des Rückenfettes} (Kurzmitteilung)

Verglichen wurden die histologischen Merkmale des Rückenfettes von Mangalitza und Ungarischen Large White bei einem Lebendgewicht von $130 \mathrm{~kg}$. Für die beiden Rassen Mangalitza und Ungarisches Large White betrugen die durchschnittlichen Fettzelldurchmesser $117.2 \pm 24.1$ bzw. $55.3 \pm 17 \mu \mathrm{m}$, die Zellgrössen $118.9 \pm 44.3$ bzw. $31.9 \pm 0.63 \mu \mathrm{m}^{2} \cdot 100$ und das Zellvolumen $8.01 \pm 0.67$ bzw. $2.18 \pm 0.18 \mu \mathrm{m}^{3} \cdot 1000$. Sie unterschieden sich zwischen den Rassen signifikant. Bei den Ungarischen Large White wurden signifikant höhere Hydroxyprolinwerte und fünffach größere Bindegewebeoberflächen (\%) nachgewiesen. Die quantitativen Ergebnisse unterstreichen die praktische Erfahrung, dass bei gleichem Lebendgewicht der Rohfettgehalt $(89.9 \pm 1.19$ bzw. $78.9 \pm 0.39 \%)$ und der Trockensubstanzanteil $(97.8 \pm 1.72$ bzw. $87.7 \pm 0.38 \%)$ des Rückenfettes, sowie die Zellularität beider Rassen erheblich unterscheiden.

Schlüsselwörter: Schwein, Mangalitza, Ungarisches Large White, Rückenfett, Bindegewebe, Histologie 


\section{Introduction}

At present, divergently selected pig genotypes (from lean to fat) produce bacon products, Mangalica representing a special position over the meat-producing genotypes due to its superior bacon quality traits (ENDER et al. 2002). The preference of Mangalica is primarily bound to its fat production (EGERSZEGI et al. 2003). In this regard SZABÓ and FARKAS (2001) published detailed results on the fatty acid composition of adipose tissue with lower saturated (stearic acid) (CSAPÓ et al. 1999), and higher monounsaturated (oleic acid) proportions, as compared to meat-type genotypes, with fully identical feeding (VOLK et al. 2004). Thus, adipose tissue fatty acid profile may also play a role in shaping the consistency of Mangalica bacon.

In pigs, nutritional manipulation does not affect the number of extramuscular adipose cells (LEE et al. 1973b). Porcine adipocyte proliferation is limited to a short postnatal period (DESNOYERS et al. 1980), thus adipose tissue volume is primarily depending on the fat-filling (hypertrophy) of the existing preadipocytes or small adipose cells. To assess genotype-associated differences, comparison at identical bodyweight in the adulthood is the most widely applied strategy (LEE et al. 1973a,1973b, CORINO et al. 2005, FISCHER et al. 2006, VACLAVKOVA and BECKOVA 2007), when hyperplasia is not active.

However, there is lack of controlled studies on the adipose tissue, and in particular, on its connective tissue moiety of the highly important Hungarian Mangalica breed. Thus, the present study aimed to describe and compare some backfat histological characteristics of Mangalica and Hungarian Large White pigs, at identical bodyweight values.

\section{Material and methods}

\section{Animals}

Mangalica and Hungarian Large White castrates were compared ( $n=3-3)$. The bodyweight of pigs was highly similar (Table 1), while the keeping was extensive for Mangalica. Both pig genotypes were bedded on straw, had ad libitum access to water. Mangalica pigs had an access to free-range scavenging on a fence-limited paddock, while Hungarian Large White were kept closed. Adipose tissue samples were collected at the slaughter, by dissecting them from the halved bodies at the third cervical vertebra, at $10.5 \mathrm{~cm}$ off the carcass midline; backfat thickness was measured at this location. All samples showed a typical two-layered structure, divided with a connective tissue barrier. In all instances the subcutaneous layer was analysed.

\section{Diets}

The nutrient composition of the two fattening diets was basically similar, as assessed from the packages, and as shown in Table 2. For both genotypes dosed feeding was applied. Since Mangalica keeping was extensive, which is the conventional and characteristic keeping mode of this breed, the composition of the additional feed components was unknown. 
Table 1

Biological characteristics of the pig genotypes and their adipose tissue samples

Biologische Merkmale der Genotypen der Schweine und ihrer Fettgewebeproben

\begin{tabular}{lccc}
\hline & Mangalica & Hung. Large White & $P$ (t-test) \\
\hline $\mathrm{N}$ & 3 & 3 & - \\
Bodyweight, $\mathrm{kg}$ & $132 \pm 9$ & $130 \pm 8$ & $>0.05$ \\
Age at slaughter, days & 310 & 228 & - \\
Backfat thickness, $\mathrm{mm}$ & $49 \pm 6$ & $24 \pm 5$ & $<0.05$ \\
Hydroxyproline, wet tissue wt\% & $0.04 \pm 0.005$ & $0.23 \pm 0.014$ & $<0.001$ \\
Collagen, wet tissue wt\% & $0.26 \pm 0.03$ & $1.73 \pm 0.1$ & $<0.001$ \\
Fat content, wet tissue wt\% & $89.90 \pm 1.19$ & $78.90 \pm 0.39$ & $<0.001$ \\
Dry matter, $\%$ & $97.80 \pm 1.72$ & $87.70 \pm 0.38$ & $<0.001$ \\
Cell diameter, $\mu \mathrm{m}$ & $117.20 \pm 24.1$ & $55.30 \pm 17$ & $<0.0001$ \\
Cell area, $\mu \mathrm{m}^{2} \cdot 100$ & $118.90 \pm 44.3$ & $31.90 \pm 0.63$ & $<0.0001$ \\
Cell volume, $\mu \mathrm{m}^{3} \cdot 1$ 000 & $8.01 \pm 0.67$ & $2.18 \pm 0.18$ & $<0.0001$ \\
Area\% of connective tissue in the adipose tissue & $3.57 \pm 0.65$ & $11.38 \pm 1.62$ & $<0.0001$ \\
\hline
\end{tabular}

Table 2

Nutrient composition of the diets

Futterzusammensetzung

\begin{tabular}{lcc}
\hline & Mangalica & Hungarian Large White \\
\hline Dry matter, \% & 88.4 & 88.0 \\
Metabolizable energy, MJ/kg & 13.5 & 13.7 \\
Digestible energy, MJ/kg & 13.6 & 13.9 \\
Crude protein, \% & 11.8 & 12.0 \\
Crude fat, \% & 4.2 & 4.0 \\
Crude fiber, \% & 5.0 & 5.0 \\
\hline
\end{tabular}

\section{Histological analysis}

Fresh tissue samples were fixed in $10 \%$ neutral buffered formalin. Sample preparation was performed with a tissue processor equipment (Thermo Shandon Pathcentre, Thermo Fisher Scientific Inc., Waltham, MA, USA). Sectioning was performed with a sledge microtome $(3 \mu \mathrm{m}$, Reichert Optische Werke AG, Vienna, Austria) from the paraffinembedded blocks, and staining was carried out with a carousel-type slide stainer (Thermo Varistain 24-4, Thermo Fisher Scientific Inc., Waltham, MA, USA), with hematoxylin and eosin, at the Kaposi Mór Hospital, Department of Pathology, Kaposvár, Hungary.

Histometrical measurements were performed on a standard PC with the ImageJ 1.41 (2002) software, on the digital images captured on a light microscope. For cell diameter calibrated line measurement was performed on 100 cells/ocular field (CORINO et al. 2005). Adipocyte size was measured with the polygon measurement method. Subsequently, cell volume was estimated according to HIRSCH and GALLIAN (1968), by the formula:

$$
C V=\frac{\pi}{6\left(3 \sigma+\bar{x}^{2}\right)}
$$

where $C V$ is the cell volume, $\sigma$ is the variance of the cell diameter and $\bar{x}$ is the mean cell diameter. For the image-based quantification of connective tissue (area\%), the green channel of images was selected, and a threshold value of 165 was applied for all images. 


\section{Chemical analysis}

Adipose tissue collagen content was determined based on its hydroxyproline content (Mersmann et al. 1973), as determined with a photometric method (MSZ ISO 3496:2000). Fat content was determined by the Soxhlet method, while dry matter content with drying in an oven at $103^{\circ} \mathrm{C}$ until constant weight.

\section{Statistical analysis}

Biometric data were compared by independent samples t-test, with the SPSS 10 (1999) software.

\section{Results}

Characteristic sections of Mangalica and Hungarian Large White adipose tissue are shown in Figure $1 \mathrm{a}$ and $\mathrm{b}$, at identical magnifications. Image analysis results obtained for cellularity and connective tissue content are shown in Table 1. Adipose cell diameter, cross-sectional area and volume, and tissue fat and dry matter content was significantly higher in Mangalica pigs, while the connective tissue content, as assessed by direct chemical and image analysis was significantly higher in the Hungarian Large White pigs. This latter property can also be recognized in the microscope images (Figure $1 \mathrm{a}, \mathrm{b}$ ). In the hydroxyproline content ca. 5 -fold higher values were found in the Hungarian Large White pigs.

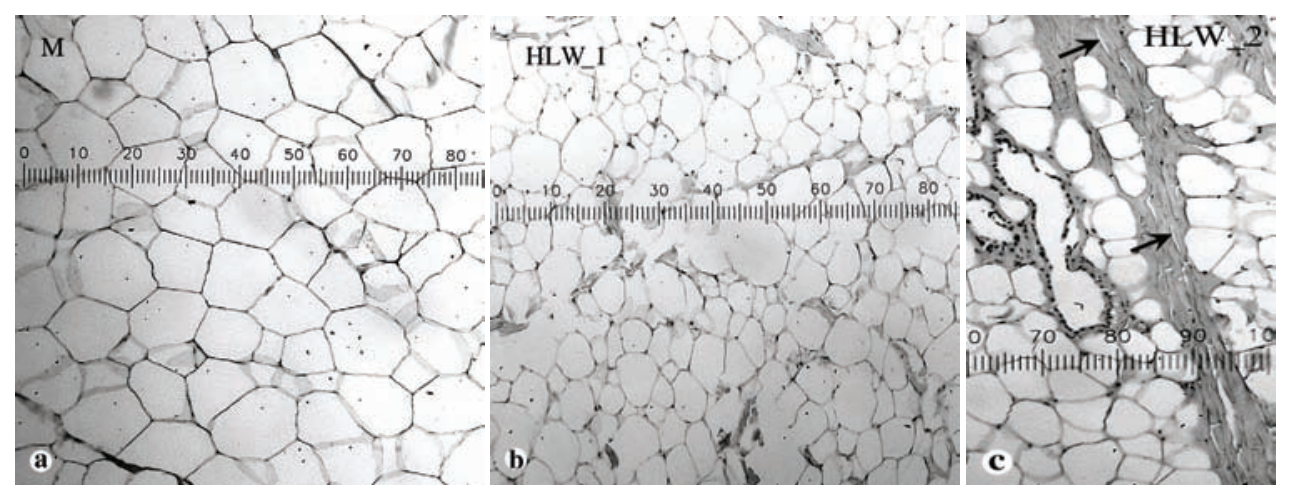

Figure 1

Mangalica (a) and Hungarian Large White (b, c) adipose tissue at 200x. 10 units on the scale bar represent $100 \mu \mathrm{m}$. Mikroskopische Abbildung des Rückenfettes beim Mangalitza und Ungarischen Large White bei 200facher Vergrößerung. 10 Einheiten auf der Skala entsprechen $100 \mu \mathrm{m}$.

\section{Discussion}

The propensity of pigs to fatten depends largely on genetical factors (HOOD and ALLEN 1977), as the final fat cell number is reached at a rather early age (LEE and KAUFFMAN 1974, DESNOYERS et al. 1980). Thus, at constant bodyweight total body adiposity is a correlate of adipose cell volume (HOOD and ALLEN 1977). More progressed cell hypertrophy and cellular fat content at identical weight refers to an excessive lipogenesis and a consequent fat accretion, as found in the Mangalica pigs in the present study, since in 
swine the site of de novo lipid synthesis is primarily the adipose tissue (STEELE et al. 1974). It is widely accepted that selection had a secondary influence on the lipogenic activity of adipocytes of lean and fat swine breeds, but altered the developmental stage at which maximal lipogenic ability is manifested. This is consonant with the large age and tissue dry matter content difference between the animals of the present study, meanwhile age basically determines the extent of adipose tissue development, manifesting also in prenatal differences among pre-obese and lean foetuses (TRUSTY and HAUSMANN 1990).

A basic aspect of investigating the connective tissue moiety in adipose tissue is that collagen deposition and lipid accretion are separately controlled in swine (HAUSMAN and KAUFFMAN 1986). Connective tissue fibers were more expressed in Hungarian Large White, and were less frequently occurring in Mangalica. Merely in Hungarian Large White, at some infrequent sites adipocyte groups, surrounded by loose connective tissue fibers were also recognized in the sections. These fat cells were spindle-shaped or smaller than the majority of adipocytes (Figure 1c, marked). MERSMANN et al. (1975) reported similar findings in newborn piglets, with higher frequency, suggesting an earlier developmental stage of adipose tissue Hungarian Large White pigs, as compared to Mangalica, where these were absent.

In conclusion, the comparison of adipose tissue at identical bodyweight provides quantitative evidence for the more expressed lipogenesis (larger cell size) of Mangalica and an earlier developmental status of Hungarian Large White (dry matter), with overt small cells and a higher connective tissue contribution.

\section{Acknowledgements}

The support of the Hungarian Academy of Sciences to A. Szabó (Bolyai János Research Grant, BO/00108/2007) is gratefully acknowledged.

\section{References}

Corino C, Di Giancamillo A, Rossi R, Domenghini C (2005) Dietary conjugated linoleic acid affects morphofunctional and chemical aspects of subcutaneous adipose tissue in heavy pigs. J Nutr 135, 1444-50

Csapó J, Husvéth F, Csapóné-Kiss ZS, Horn P, Házas Z, Vargáné-Visi É, Bőcs K (1999) Fatty acid composition and cholesterol content of the fat of different pig genotypes. Acta Agraria Kaposvariensis 3, 1-13 [in Hungarian]

Desnoyers F, Pascal G, Etienne M, Vodovar N (1980) Cellularity of adipose tissue in fetal pig. J Lipid Res 21, 301-8

Egerszegi I, Rátky J, Solti L, Brüssow KP (2003) Mangalica - an indigenous swine breed from Hungary. Arch Tierz 46, 245-56

Ender K, Nürnberg K, Wegner J, Seregi J (2002) Meat and fat from Mangalitza pigs in the lab. Fleischwirtschaft 6, 125-8 [in German]

Fischer K, Lindner JP, Judas M, Höreth R (2006) Carcass and meat quality of heavy pigs. II. Characteristics of meat and fat quality. Arch Tierz 49, 297-92 [in German]

Hausman GJ, Kauffman RG (1986): The of developing porcine adipose tissue. J Anim Sci 63, 642-58

Hirsch J, Gallian E (1968) Methods for the determination of adipose cell size in man and animals. J Lipid Res 9, 110-9

Hood RL, Allen CE (1977) Cellularity of porcine adipose tissue: effects of growth and adiposity. J Lipid Res 18, 275-84 
Lee YB, Kauffman RG, Grummer RH (1973a) Effect of early nutrition on the development of adipose tissue in pig. I. Age constant basis. J Anim Sci 32, 1312-9

Lee YB, Kauffman, RG, Grummer RH (1973b) Effect of early nutrition on the development of adipose tissue in pig. Il. Weight constant basis. J Anim Sci 37, 1319-25

Lee YB, Kauffman RG (1974): Cellularity and lipogenic enzyme activities of porcine intramuscular adipose tissue. J Anim Sci 38, 538-44

Mersmann HJ, Underwood MC, Brown LJ, Houk JM (1973) Adipose tissue composition and lipogenic capacity in developing swine. Am J Physiol 224,1130-5

Mersmann HJ, Goodman JR, Brown LJ (1975): Development of swine adipose tissue: morphology and chemical composition. J Lipid Res 16, 269-79

Rasband WS (1997-2005) ImageJ, U.S. National Institutes of Health, Bethesda, Maryland, USA, http://rsb.info.nih.gov/ij/ [last accessed 06.01.2010]

SPSS 10 (1999) SPSS Inc. Chicago, IL, USA

Steele NC, Frobish LT, Keeney M (1974) Lipogenesis and cellularity of adipose tissue from genetically lean and obese swine. J Anim Sci 39, 712-9

Szabó P, Farkas T (2001) The fat content and composition of Mangalica pigs. A Magyar Elhízástudományi Társaság II. kongresszusa és a Magyar Elhízásellenes Alapítvány XVI. országos konferenciája. Dobogókő, 17-18. [in Hungarian]

Trusty CD, Hausmann GJ (1990) In vivo studies of lipid metabolism in lean and pre-obese swine. Int J Obesity 14, 21-9

Vaclavkova E, Beckova R (2004) Effect of linseed in pig diet on meat quality and fatty acid content. Arch Tierz 50 Special Issue, 144-51

Volk B, Biedermann G, Kuhn M, Jatsch C (2004) Influence of different genetic origins on fattening and carcass Performance, on quality of meat and fat as well as fatty acid pattern of phospholipids from pigs. Arch Tierz 47, 455-62 [in German]

Received 4 May 2009, accepted 6 January 2010.

Corresponding author:

ANDRÁS SZABÓ

email: szan1125@freemail.hu

Laboratory of Animal Product Qualification, Faculty of Animal Science, Kaposvár University, Guba S. u. 40, 7400 Kaposvár, Hungary 